\title{
Veil, a Need of Human BIOS: Study beyond Religions
}

*Syed Aftab Alam ${ }^{1} \& * *$ Naseem Akhtar ${ }^{2}$

\section{ABSTRACT}

Generally, it is understood that religions are the basic foundations of women veil-acceptance and projection in present societies but the study of ancient communities beyond the birth of Semitic Religions evident that in approximately all parts of the globe, the women used to wear the full body covering dresses and somewhere face veil also. Due to attaining physical enchantment or necessity of climate, dresses or head covering were somewhat different but females were used the veil of body and face all the times.

Human being, man and women, has a constant human BIOS (Basic Input \& Output System). Human BIOS has fixed needs and defined actions which cannot be changed or corrupted due to diseases or accidents. Human BIOS consists on skill of speaking, hearing, smelling, seeing, eating, defending, making itself beautiful, saving body or self, covering the body and loving other sex. Human BIOS of women has some specific characteristics also like shyness, fear by exposing body and love for decorating her body.

\footnotetext{
${ }^{1}$ Assistant Professor, Department of Islamic Studies, Fatima Jinnah Women University Rawalpindi Pakistan, Aftab.alam@fjwu.edu.pk

2 Assistant Professor, Department of Islamic Studies, Shaheed Benazir Bhutto Women University Peshawar Pakistan, nsm_aktr@yahoo.com
} 
These characteristics of women BIOS urges and urged them to cover their bodies and heads with veil.

This article consists of study of women practices of veiling in ancient communities, explanation of women BIOS, female natural urge for covering and decorating their bodies. All of this study is on humanitarian basis beyond the boundaries of religions. The article explained that philosophical pathology of veil elucidated the actual bases of veil adaptation among women. Of course World Major Religions depict a social phenomenon that there is no ban on women to use veil and additionally, religions advocate modest or full body covering dresses and presents veil of full body of women as a mark of honor, dignity and modesty among all communities of the world but the article revolves around the veil adaptation only by women BIOS sphere.

Keyword: Veil, Human BIOS, covering body, Semitic Religions, ancient communities, decorating body

\section{INTRODUCTION:}

It is, generally, accepted that women adopted veil due to the teaching of their religions $\left({ }^{1}\right)$. It is also projected that women veiling system in Islam, Christianity and Judaism is based on the preaching of these religions $\left({ }^{2}\right)$. The oldest religion of Semitic religions has age about 2500 years but social scientists have evidences that women were also using veil in their daily life before 2500 B.C. years ago. $\left({ }^{3}\right)$ 
The oldest scriptures narrated the story of Adam and Eve and introduce the adaptation of veil or covering body parts. $\left({ }^{4}\right)$ It can be the start of veiling adaptation but history tells that in very ancient times, women were used to wear veil in their public life and men were used to promote veiling system in their family life.

It is therefore needed to study the aspects of veil-adaptation in ancient eras to research out the real derivations of veil acceptance and promotion. It is needed to study the humanitarian aspects of veil adaptation. Each individual of this universe has a specific Input and Output System according to its own requirements and characteristics. This Human Basic Input and Output System BIOS are naturally built-in in each and every individual of this universe. It is God gifted. It is naturally programmed and automatically activated.

Human being has also a Basic Input and Output System, and I have given it the name "Human-BIOS" $\left({ }^{5}\right)$. Human BIOS is also naturally build-in system and remain activated from initial birth to death. Human being is already programmed with seeing, hearing, feeling, walking, eating and thinking skills. These skills and powers are not learnt by any institution. Everyone can open the eyes, rotate and focus the eyes, save the eyes and show love or anger through eyes gestures. Similarly, all these skills are already programmed in human being so these are the basic characteristics of human being. On the base of these Input and Output System, basic study spheres i.e. philosophy, psychology, emotions and social sciences have been developed. Actions of human being can be study on psychological, philosophical and emotional grounds and study to adapt the veil on these aspects can provide the actual derivations of veil adaptation. 


\section{OBJECTIVES OF THE STUDY:}

1. To study the roots of veil assuming.

2. To explore the different kinds and aspects of veil-adoptbasis.

3. To search out the start of veil take on by humankind.

4. To research the intensity of women inclination to adopt veil in ancient eras.

\section{SIGNIFICANCES OF THIS STUDY:}

1. Knowledge about fundamental causes of using veil system in ancient times.

2. Birth of veiling system among women and the birth of civilizations are age fellows.

3. Veiling system is naturally inherited in life.

4. Philosophical, social, economic, ethical and psychological basis of veil adopt.

\section{HYPOTHESIS OF THE STUDY:}

Hypotheses were generated to declare the expected results of the research. In context with this research, under given hypothesis were formulated.

$\mathrm{H}^{1}$ : Veiling is naturally inhibited in human nature.

$\mathrm{H}^{2}$ : Philosophical perception by some ancient communities and pathologies, men drew themselves away from women, resultantly; women concealed themselves to enhance their importance against males.

$\mathrm{H}^{3}$ : Physical weakness of women than men and a sheer insure ancient social atmosphere pushed men and women to get adopt veil in women's live.

$\mathrm{H}^{4}$ : $\quad$ Psychological inferiority complex among women urged them to get upon veil to conceal the short comes and detrack the mental approach of men. 
$\mathrm{H}^{5}$ : Economical superiority and manliness of man granted authority to him over women so he forced them to cover themselves as their property.

\section{REVIEW OF THE LITERATURE:}

Human BIOS have fundamental skills i.e. speaking, hearing, smelling, seeing, eating, defending and making beautiful. These actions of human being are study under the subjects of psychology, philosophy and sociology.

According to Socio-historic point of view, there are five basic factors i.e. psychological, economic, philosophical, ethical, and social those develop the veiling system among women in the history of mankind.

\section{PHILOSOPHICAL ROOTS:}

The philosophical base of adaptation veil is a tendency to act upon asceticism and hatred for gaining pleasure by women. Saint Paul speaks for his own asceticism, he writes about penalizing his physique as a hard taught athlete "in order to subordinate it to reason in the service of the Gospel" $\left({ }^{6}\right)$. Jerome described that writers from Christian especially old communities like Augustine, Jerome, Chrysostom and Origen etc. inferred the Biblical texts to establish a "highly Ascetic zed religious environment" ${ }^{7}$ ).

It is evident that from the early ages of Christianity life "St. Paul developed the thinking of such celibacy that people should adapt celibacy to destroy the Satan so there was a number of people who encouraged on this life pattern and moved to the away from social life to crush the element of Satan into themselves. Russell stated that as per the saying of St. Paul, "cleanliness of the body 
opposed the cleanliness of the spirit and lice come to be considered as 'pearls of $\operatorname{God}^{\prime}\left({ }^{8}\right)$.

In Hinduism, Asceticism can be seen in the form of Sadhus, it is a severe form of Asceticism. Olivelle depicted, "They abstain themselves from women and sensual pleasures" $\left({ }^{9}\right)$.

Monks and Nuns practice complete celibacy. Frank, et al., elucidated that Monks and Nuns are so strict to avoid even "touch or share the sitting platform" $\left({ }^{10}\right)$.C: :Users\Zeeshan\Downloads〉 It is such base that having long hair among the Faqeers, in Asian countries, Bakhtiar who, "practiced asceticism and remained celibate from women" $\left({ }^{11}\right)$. The theology was promoted and encouraged by the religious leaders of India and later a barrier of persuasion of asceticism had been established between women and men of Hindu society. Bakhtiar further stated, due to the same theory, that "a woman is the highest form of lustful pleasure" $\left({ }^{12}\right)$.

It is a human psychological operation that when someone is rejected, the person conceals himself. When anything loses its attraction and importance, it makes covered and neglected. Therefore, the veil (Purdah) was appeared among women, in an absolute opposite reaction, due to the philosophy of asceticism.

\section{SOCIAL INSECURITY ROOTS:}

Another base for adopting veil (Purdah) is the fear of womeninsecurity. There was lack of security especially for beautiful women, which had developed in many societies of the world.

Insecurity can be defined in these words that person feel unease and unsecure due to any sort of fear of danger or hurt. Erik \& Steven illustrated as "Insecurity may cause shyness, paranoia and 
social withdrawal" $\left({ }^{13}\right)$. It is found that as much as greater insecurity, the level of isolation will be as much as higher.

Bakhtiar stated a complete incident as Anushiravan, an East King, had a Major in his army who had a beautiful wife. Anushiravan sent the Major on a petition at a far place out of the city and in the absence of the Major; he approached to the wife of the Major. Later, the wife informed her husband Major about the sick approach and sexual abuse of Anushiravan. The Major left the wife due to unbearable pain into his heart. Anushiravan was informed that the Major had divorced his wife. When Anushiravan saw the Major he said, "I understand you had a beautiful garden that you left over. Why?" The Major said. "Your majesty, I saw footprints of lion in the garden and I was afraid the lion would eat me." Anushiravan laughed." ( ${ }^{14}$ )

Thus, there was no security. Everyone lived in fear so another base for the appearance of the women veil (Purdah) in ancient era was insecurity.

\section{ECONOMICAL SNUB / ROOTS:}

Another base studied out for veiling (Purdah) is economic exploitation of women by men. Man enforced veiling and restricted women at home to snub her activities of economic advantages because he wanted to get upper hand over women through her feeding and to satisfy his instinct. Cunningham explained with the (first era being communal, then the feudal era, the era of capitalism and the era of communism). $\left({ }^{15}\right)$

In modern world, economical injustice of women is called in new term "Economic Abuse". The Advocate for Human Rights 
magazine published that "Economic abuse is when the abuser has control over the victim's money and other economic resources." $\left.{ }^{16}\right)$

American Civil Liberties Union published a report, in which it proclaimed that "Due to Economic Abuse of women isolation of women urges" $\left({ }^{17}\right)$, it is explained that if a women has very little sources to meet her daily life, she feels very unsecure and due to this financial insecurity, she become isolated and felt loneliness.

It is further elucidated by American Civil Liberties Union, "these policies can cause them to face eviction" $\left({ }^{18}\right)$, which causes many victims as Waal described "to remain without the assistance they need". $\left({ }^{19}\right)$

Is it true that economical snub of women was/is existed, even now, in those places of the world where the veil (Purdah) is not practiced and by and by in past and now, also peoples were/are turning to adopt veil.

\section{ETHICAL EGOISM RATHER SELFISHNESS OF MAN:}

Another base was searched out for appearance of the veil (Purdah) was ethical attitudes of men for women. Sanders defined "Selfishness denotes an excessive or exclusive concern with oneself" $\left({ }^{20}\right)$, it is beyond the act of placing one's own needs or desires above the needs or desires of others.

In other words, Rational and Ethical egoism are two different elements in sociology, which is further illustrated by Jefferson that "it is rational to act in one's self-interest." $\left({ }^{21}\right)$ These theories are combined in sociological pattern but have different spheres of study. 
Weber emphasized "as morality basis, Self-interest, or self-love, or egoism, has been more plausibly substituted." $\left({ }^{22}\right)$

The regulation might license persons to use viciousness in protection of self or stuff, but when there is part of self-ego and self-centeredness, the case is different. Russell stated, "Capability to practice power has been settled by the self, and only by the self." $\left({ }^{23}\right)$

The man, due to selfishness, self-interest, egoism and jealousy for other men imposed veil for women so that he can enjoy exclusively with her. This is a form of excessive greed of sex, which ultimately imposes the veil on women. Russell had vision that man is able to some extent; he is not fully able or expert in any matter of life. He said that human being can overcome the greed of wealth but human being is unable to "control their greed for sex". $\left({ }^{24}\right)$

It is rather due to selfishness or jealousy of man to dominate over women than manliness or zeal that man practiced to put a veil and restrict his women into the house. By and by, women accustomed to veil into different societies based on this ethical attitude of man.

\section{PSYCHOLOGICAL ROOTS:}

It is also found that imposing of veil (Purdah) and women kept bound till the boundaries of home $\left({ }^{25}\right)$ is based on psychological aspects. From beginning, women have inferiority complex $\left({ }^{26}\right)$ before man that she has less organic power in her body than man and second that she has bleeding monthly period which disturbs her many capacities in comparison with man. 
These types of psychological abuses created inferiority complex into women. Women in ancient times and even in some societies of today also have both types of inferiority feelings $\left({ }^{27}\right)$. In psychological reaction of these feelings, women pulled a veil over them and concealed themselves.

Another big reason that societies adopted veil was reaction of inferiority complex of women. They concealed themselves before men to overcome their shortcomings and blamed inferiority.

\section{JOURNEY OF THE VEIL}

The literature has been reviewed on the basis of women actions of veil adaptation in ancient eras through their philosophical, psychological and social aspects. Religious aspect of veil adaptation is out of this study because religions were introduced later. It is found that religions especially Semitic religions advocate and adapt veiling systems for their adherents but veiling system is not totally based on Semitic religions' preaching.

The great change came as result of the two world wars and the depression. In the 1920s "the hemline of the dress inclined up to just below the knee" $\left({ }^{28}\right)$. It would take another thirty years to pants and shorts to gain wider acceptance and forty years or so for hemlines to rise above the knee. The beginning of the end for the covered was already underway by the 1920's. In 19th century America most women covered their hair when going out $\left({ }^{29}\right)$. They used bonnets and fitted caps to do this. In the latter years of the 1800's hats came into fashion, stayed in fashion, and have never become entirely unfashionable $\left({ }^{30}\right)$. The hat did, however, become an item of clothing that most people only wear for weather protection. We can still find fashionable hats on sale in 
better department stores. It has been said by some wise person that if even one generation stops a certain practice, it will be as if the practice had never happened. For an example you need only to look at breast feeding to see what happens when people stop a certain practice even for a couple of generations. This is what happened to the head covering. It is not that everyone stopped this practice; everyone did not stop wearing the head covering. Enough people stopped wearing it that people forgot that most women once wore it and they forgot why it was worn. "By their fruits ye shall know them." $\left.{ }^{31}\right)$

\section{CONCLUSIONS:}

This study concluded that humanity, from ancient era to present times, is observing veiling in different styles and phenomenon. All hypotheses are positively affirmed, which depicts that there are five basic roots to adopt veiling system and prevail among different communities, cultures and areas of the world beyond the bondages of religions. 


\section{References}

${ }^{1}$ Marianne Kamp and Noor Borbieve, "Veiling and Unveiling in Central Asia: Believes and Practices, Tradition and Modernity in The Routledge International Handbook to Veils and Veiling Practices edited by Anna-Mari Almila and David Inglis, (London and New York: Routledge, Taylor \& Francis Group), P.86-89

${ }^{2}$ Ibid, p. 90

3 Doreen Yarwood, 1978, "Illustrated Encyclopedia of World Costume", (New York: Dover Publication Inc.), p. 285-289

${ }^{4}$ Ibid, p.478

${ }^{5}$ The term Human BIOS is introduced by the author. For example, each human feel pleasure at seeing smiling face and feel agony and mental disturbance at the sight of cruelty. Each one knows the concept of love, hate, sincerity and pleasure but no one has been taught by parents or teachers verbally but only conceptually. The system is already programmed into human "Self".

${ }^{6}$ The Holy Bible with an explanatory and Critical commentary by Bishop and other Clergy of the Anglican Church, 1611AD, edited by Cook, F.C., (New York: Charles Scribner's Sons), p.94

7 Jerome St., 2005 "New Advent - Catholic Encyclopedia: Asceticism", (Las Hermanas: Bacon and Lara Press, 2005), Vol. I

${ }^{8}$ Russell Bertrand, 1929, "Marriage and Morals", (London: George Allen \& Unwin Ltd.,) p. 30

${ }^{9}$ Olivelle Patrick, 1996, "Rules and Regulations of Brahmanical Asceticism" translation of Yadava Prakasa's book, (Delhi: Sri Satguru Publications), p. 154

${ }^{10}$ Frank William, et al., 1964, "A History of Asia", (London: Allyn and Bacon), p. 235 
${ }^{11}$ Bakhtiar Lelah, 1998, "The Islmic Hijab-modest dress" (Tehran: Islamic Propagation Organization), p.68

12 Ibid, p. 31

${ }^{13}$ Erik A. Fisher \& Steven W. Sharp, 2004, "The art of Managing everyday conflict", (Westport, CT: Greenwood Publishing Company), p.52

${ }^{14}$ Ibid 6, p.42

15 Cunningham John M., 1998, "Drafting Limited Liability Company Operating Agreements", 'Economic Abuse", (NY: Aspen Publishers Online), p.890

${ }^{16}$ The Advocate for Human Rights, "Stop Violence Against Women", (MN, USA: April 2010), retrieved from http://stopvaw.org/domestic_violence and_housing.html

${ }^{17}$ American Civil Liberties Union, "Women's Rights Project”, (New York: ACLU Foundation, 2007), retrieved from http://www.aclu.org/FilesPDFs/ housing\%20paper.4.pdf.

${ }^{18}$ Ibid, p. 2

19 Waal Frans D., 2009, "Primates and Philosophers: How Morality Evolved", (NJ, USA: Princeton University Press), retrieved from http://press.princeton.edu/titles/8240.html, p.13

${ }^{20}$ Sanders Steven M., 1988, "Is egoism morally defensible? Philosophe", (Netherlands: Springer), Vol. XVIII, p.2

${ }^{21}$ Jefferson Thomas, 1814, "The Moral Sense. Teaching American History", (NJ, USA: Princeton University Press), p.128

${ }^{22}$ Weber Max, 1997, "The Theory of Social and Economic Organization", (New York: Simon and Schuster), p.154

${ }^{23}$ Kirby Peter, 2001, "The First Epistle of Paul: the Apostle to the 1 Corinthians, 9:25", American Standard Version, (USA: Early Christian Writing), p.82 
${ }^{24}$ Ibid, p.86

${ }^{25}$ Barbra Cassada, 2002, "Women Remove Thy Veil" (Cambridge: The Lion's Heart Ministries Inc., p.119

${ }^{26}$ Georgio Cavvallini, 2015, "General Therapeutic Approach to Male Infertility", in Clinical Management of Male Infertility Edited by Giorgio Cavallini and Giovanni Beretta, (New York and London: Springer Cham Heidelberg), p.34

${ }^{27}$ Ibid, p.107

28 Jayne Shrimpton, 2014, "Teaching Your Ancestors Through Family Photographs: A Complete Guide for Local and Historians" (Great Brittan: Pen and Sword Book Ltd.), p.81

29 Tulla Lightfoot, 2019, "The Culture and Art of Death in $19^{\text {th }}$ Century America", (North California: McFarland \& Company, Inc. Publishers), p.141 30 . Ida Tomshinsky, 2013, "The Chronicle of Hats in Enjoyable Quotes: History of Fashion", (London :Xibris Corporation), p.25

${ }^{31}$ Martha Farquharson, 2017, "Ella Clinton Or by Their Fruits Ye Shall Know Them", (California: Create Space Independent Publishing Platform), p.90 